Edward T. Crosby BSc MD FRCPC, * Stephen H. Halpern MD FRCPC,* Stephen H. Rolbin MDCM FRCPC $\dagger$

\title{
Epidural anaesthesia for Caesarean section in patients with active recurrent genital herpes simplex infections: a retrospective review
}

The safety of epidural anaesthesia in patients with active. recurrent genital herpes simplex (HSV) infections is controversial. We reviewed the six-year experience of the use of epidurat anaesthesia in this patient population in two institutions. Eighty-nine parturients with active genital HSV were administered epidural anaesthesia for Caesarean section. No patient suffered an adverse outcome related to either the anaesthetic or the virus. The theoretical risks of regional anaesthesia in the parturient with active herpes genitalis are reviewed. We conclude from available data that the risk of an adverse outcome is small and does not contraindicate the use of epidural anaesthesia in patients with recurrent infection.

\section{Key words}

ANAESTHESIA: obstetrical: ANAESTHETIC TECHNIQUES: epidural; INFECTION: herpes simplex, genital.

From the: Department of Anaesthesia, \&Women's College Hospital and $†$ Mount Sinai Hospital, University of Toronto.

Address Correspondence to: Dr. E.T. Crosby, Department of Anaesthesia, Women's College Hospital, 76 Grenville Street, Toronto, Ontario, M5S 1B2.

1 Joyce $T H$, Marx $G F$. Regional anaesthesia and herpes. Soc Obst Anesth Perinatol Newsletter 1983; 14: 1,6.

2 Bassell GM. Editorial. Obstet Anesth Digest 1982 (Sept), 92.
In the last two decades there has been a dramatic increase in the incidence and prevalence of genital herpes simplex (HSV) infections in the North American population, much of it occurring in the reproductive-age population. ${ }^{1}$ Parturients with a confirmed history of genital herpes infections are often delivered by caesarean section to minimize exposure of the neonate to the virus. Some anaesthetists, concemed about the possibility of introducing virus into the central nervous system in these patients, either do not use or advise against the use of regional anaesthesia for Caesarean section. We report our experience with lumbar epidural anaesthesia for Caesarean section in patients with recurrent herpes infections.

\section{Methods}

The study population was drawn from patients admitted to either Women's College Hospital or Mount Sinai Hospital between January, 1983 and December, 1988. Following institutional approval, the charts of all patients admitted for Caesarean section, with the diagnosis of genital herpes (HSV) infections, were studied. The following patients were identified: (1) patients with herpetic lesions identified at the time of presentation for delivery; (2) patients who had experienced an outbreak of herpetic lesions within one week before delivery; and (3) patients who had a positive culture or smear for HSV within one week of delivery. Patients meeting one or more of the above criteria were deemed to have active disease and their charts were further analysed.

The anaesthetic record was reviewed and the mode of anaesthesia was recorded. Complications related to the administration of the anaesthetic were noted. For those patients who received general anaesthesia (GA), the anaesthetic record was further reviewed to obtain a specific reason for the use of GA. The use of epidural narcotics for postoperative analgesia was recorded. Inhospital, maternal postoperative course was reviewed for: (1) the presence of signs and symptoms of meningitis or 
TABLE I Annual caseload 1983-88

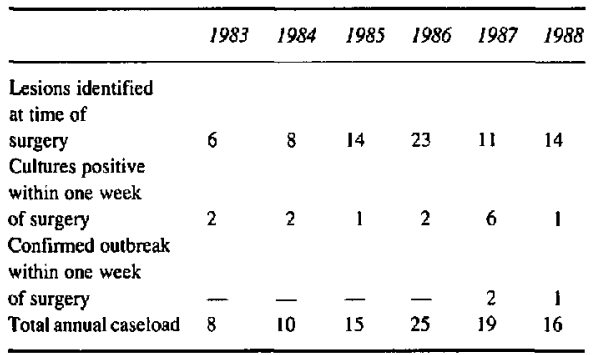

encephalitis; (2) development or exacerbation of herpetic outbreaks; (3) evidence or an anaesthetic-related complication; or (4) evidence of other septic or neurological complications.

The nursery course of all babies was reviewed for the presence of neonatal herpes infection.

\section{Results}

There were 144 patients admitted for Caesarean section with the diagnosis of genital herpes infections during the period of study. All patients identified had a previous history of genital herpes and were classified as having recurrent disease. Fifty-one patients, 35 per cent, had a history of genital herpes but did not meet our criteria for active disease and were excluded from further analysis.

There were 93 patients, 65 per cent, with active disease, 76, 82 per cent, of whom had lesions identified (Tables I and II). Of the 17 patients, 18 per cent, who did not have lesions identified, 13 had had positive cultures for virus within the week, one patient was positive for virus within 24 hours (electron microscopy) and three patients had suffered an outbreak of herpetic lesions within the week before delivery.

Eighty-nine of the 93 patients with active disease, 96 per cent, received epidural anaesthesia for Caesarean section. In four, epidural catheter placement was complicated by blood vessel puncture. The catheters were re-sited and the anaesthetic proceeded without further complication. Eighteen patients received epidural injections of morphine following the delivery of the infant and the average dose was $4.8 \mathrm{mg}$. Four patients received general anaesthesia, two patients at their request. Two patients had herpetic lesions at or near the proposed site of epidural insertion and the epidural was deemed to be contraindicated by the attending anaesthetist.

The average postoperative stay was 6.5 days (range 3-20 days). Five patients, 5.4 per cent, developed postoperative wound infections or endometritis and were treated with intravenous antibiotics. Postoperative stay
TABLE II Site of herpetic lesions

\begin{tabular}{ll}
\hline Site & Patients \\
\hline Genital/perineal & 70 \\
Buttocks & 2 \\
Back & 1 \\
Sacral & $1^{*}$ \\
Unspecified & 3 \\
\hline
\end{tabular}

*Also genital/perineal.

for these patients averaged 10.8 days. One patient who had been culture-positive before surgery developed an outbreak of herpetic lesions in the early postoperative period. She had not received an epidural morphine injection. There were no other septic complications and no patient developed an anaesthetic or neurological complication.

One neonate was diagnosed as having Trisomy 21. There were no episodes of herpes infections diagnosed during the nursery course of any neonate.

\section{Discussion}

Herpes simplex viruses (HSV) are members of the herpes group of viruses and humans are the only known natural hosts. ${ }^{2}$ The two major types of HSV are type 1 (HSV-1) and type 2 (HSV-2). The HSV are transmitted by direct contact with infected secretions, HSV-1 by oral secretions and HSV-2 by sexual contact, predominantly. Both viruses share the properties of latency and reactivation, residing in neural ganglion cells during their periods of latency.

Herpes simplex vinus-2 is isolated from 93 per cent of patients with primary genital infections and 98 per cent of those with recurrent infections. ${ }^{3}$ The remainder of the isolates are HSV-1. Systemic symptoms are associated with 67 per cent of primary genital HSV infections. Aseptic meningitis and sacral neuropathy is seen in eight per cent and two per cent, respectively, of patients with primary infrections. In contrast, systemic symptoms are uncommon in recurrent disease and 25 per cent of recurrent infections are asymptomatic. An immunologically specific reaction consisting of neutralizing antibody (humoral response), immune lymphocytes (cell-mediated response) and nonspecific inflammatory cell inhibition of viral replication and cell-to-cell transfer result in the localized nature of the recurrent infection. ${ }^{4}$

Recurrent genital infections with HSV afflict 0.5 to 1.0 per cent of pregnant women. ${ }^{5}$ The risk of recurrence is $0.3-0.44$ recurrences per month. ${ }^{1,3}$ During a recurrence, virus is shed for 1 to 13 days. ${ }^{6}$ Asymptomatic shedding of virus is common and 1.4 per cent of women with a confirmed history of recurrent infection will have virus in 
the lower genital tract at the onset of labour. ${ }^{7}$ Based on this rate of asymptomatic shedding and the incidence of neonatal herpes in patients entering pregnancy with recurrent herpes, the risk of an infant acquiring a neonatal infection after passing through a birth canal with virus present is probably less than five per cent. ' Despite this, 30 to 50 per cent of patients with a history of recurrent HSV-2 infections are delivered by caesarean section. ${ }^{1}$

Two issues of concern to an anaesthetist considering the use of regional anaesthesia in this population are: (1) the risk of introducing virus into the central nervous system during performance of either an epidural or a spinal anaesthetic, and (2) the likelihood of disseminated infection occurring following a regional anaesthetic that may be temporally associated with the anaesthetic despite the lack of causal relationship. There are no case reports in the English medical literature documenting introduction of HSV into the central nervous system during performance of a regional block. Disseminated herpes infections in otherwise healthy parturients have been reported. ${ }^{8-10}$ These patients typically presented as seriously ill, in the third trimester. Hepatitis is the predominant clinical feature and maternal mortality is 50 per cent. It is important to note that these infections have been associated, exclusively, with primary herpes infections. The pregnancy-associated depression of cell-mediated immunity is hypothesized to be a major factor. ${ }^{11}$ There are no case reports which document disseminated or isolated central nervous system disease in otherwise healthy parturients with recurrent herpes genitalis.

Ramanathan reported on the use of epidural anaesthesia for Caesarean section in patients with recurrent genital herpes infections. ${ }^{12}$ of the 48 patients who received epidural anaesthesia for delivery, 34, 75 per cent, had active disease manifest by lesions. Ranvindran reported on the use of epidural anaesthesia for Caesarean section in 30 patients in the presence of HSV-2 infection. ${ }^{13} \mathrm{We}$ report on the use of epidural anaesthesia in 89 patients with active, recurrent genital HSV infections. Including the current series, 153 obstetrical patients with recurrent genital HSV infections have been reported to have received epidural anaesthesia for Caesarean section. No patient, in any of the reported series, has developed a septic or neurological complication related to the anaesthetic. This does not exclude the possibility of an adverse outcome, but the true risk can be calculated to be less than two per cent $(P=0.05) .{ }^{14}$ In fact, the likelihood of an adverse outcome is probably much lower than that, given the fact that it has never been reported.

\section{Summary}

We report the result of a six-year retrospective analysis, documenting the use of epidural anaesthesia in 89 parturients with active recurrent HSV infections without anaesthetic, septic or neurological complications. Because of the localized, low-grade infective nature of recurrent infections and the absence of documented complications following the use of epidural anaesthesia in these patients, we feel that the use of epidural anaesthesia is safe, provided that the actual site of insertion is not involved.

We restricted our analysis to patients that were at high risk for having virus present at time of anaesthetic administration. By doing so we felt that we could affirm the safety of epidural anaesthesia in parients with recurrent $\mathrm{HSV}$ infections, provided no complications were detected. However, parturients with primary HSV infections are at considerable risk for both systemic symptomatology and neurologic dysfunction. The safety of regional anaesthesia in these patients has yet to be established.

\section{Acknowledgement}

We would like to thank Yolanda Lum for her assistance in preparing this paper.

\section{References}

1 Brown ZA, Berry S, Vontver LA. Genital herpes simplex virus infections complicating pregnancy. J Reprod Med 1986; 31: 420-5.

2 Hirsch MS. Herpes virus infections. In: Scientific American Medicine V; Infectious Diseases. Rubenstein E, Federman DD (Eds.). Scientific American 1987; 7: 23: 1-7.

3 Corey L, Adams HG, Brown ZA, Holmes RR. Genital herpes simplex virus infections: clinical manifestations, course and complications. Ann Intern Med 1983; 98: 958-72.

4 Epidemiological concepts and methods. In viral infections of humans. Evans AS (Ed.). New York, 1982; Plenum Medical Book Co: 17-33.

5 Kibrick S. Herpes simplex infection at term: what to do with mother, newborn and delivery personnel. JAMA 1980; 243: 157-60.

6 Harger JH, Pazin GJ, Armstrong JA, Breining MC, Ho $M$. Characteristics and management of pregnancy in women with genital herpes simplex virus infections. Am J Obstet Gynecol 1983; 145: 784-91.

7 Arvin AM, Hensleigh PA, Prober CA et al. Failure of antepartum maternal cultures to predict the infants risk of exposure to herpes simplex virus at delivery. N Engl J Med 1986; 315: 796-800.

8 Hillard $P$, Seeds J, Cefalo R. Disseminated herpes simplex in pregnancy: two cases and a review. Obstet Gynecol Surv 1982; 37: 449-53. 
9 Wertheim RA, Brooks BJ, Rodriguez FA, Lesesne HR, Jennette $J C$. Fatal herpetic hepatitis in pregnancy. Obstet Gynecol 1983; 62: 38S-42S.

10 Young ET, Killam AP, Greene JF. Disseminated herpes virus infection. Association with primary genital herpes in pregnancy. JAMA 1976; 235: 2731-3.

11 Weinberg ED. Pregnancy-associated depression of cell mediated immunity. Rev Infect Dis 1984; 6: 814-28.

12 Ramanathan S, Sheth $R$, Turndorf $H$. Anesthesia for Cesarean section in patients with genital herpes infection: a retrospective study. Anesthesiology 1986; 64: 807-9.

13 Ravindran RS, Gupta CD, Stoops CA. Epidural anesthesia in the presence of herpes simplex virus (type 2) infection. Anesth Analg 1982; 61: 714-5.

14 Rumke CL. Uncertainty as to the acceptance or rejection of the presence of an effect in relation to the number of observations in an experiment. Triangle 1968; 8: 284-9.
Résumé

La sécurité de l' anesthésie épidurale chez des patientes atteintes d'herpès génital en phase active (HSV) est controversée. On a revu l'expérience de six ans d'administration d'anesthésie épidurale chez une population de patientes dans deux institutions. Quatre-vingt-neuf patientes ayant un herpès génital actif ont subi une anesthésie épidurale pour césarienne. Aucune patiente n'a souffert d'un effet secondaire relié soit d l'agent anesthésique ou le virus. Les risques théoriques de l' anesthésie régionale chez les patientes ayant un herpès génital actif sont revus. On conclu à partir des données, disponibles que le risque d'un effet secondaire est minime et ne représente pas une contre-indication d l'utilisation de l'anesthésie epidurale chez les patientes ayant une infection herpérique génitale récurrente. 